perature $\left(\begin{array}{lll}7 & F\end{array}\right)$ afforded the opportunity I had long been seeking. But it was some time before I could arrange suitable apparatus for its examination. A hospital ward is an awkward place for Wheatstone's bridge and delicate galvanometers. Moreover I had before found that from the peculiar condition; of the human body, the testing current, to produce accurate results, requires to be frequently reversed, for fear of opposition currents of polarisation. I am glad to see a confirmation of this observation in a verbal communication of Prof. Rosenthal to the Physiological Society of Berlin on April I 3.

It was partly to overcome this difficulty that I devised, at Mr. Preece's sugsestion, a dynamometer for alternating currents, of which the general arrangement was described in NATURE some time ago. It was also brought before the Physical Society at their June meeting in Oxford. Although severely criticised by some members of that learned body, it works extremely well, and may be, I hope, an addition to medico-electrical applianses. For the purpose of the present experiment I found that an ordinarily sensitive galvanometer, considerably damped by air-resistance, was sufficient, since by the zero methods of balancing, it is only necessary just to see the deflection before commutating; when balance is obtained, commutation has no effect on the needle of the bridge.

It would require more space than could probably be here afforded to give all details of the experiments, which, moreover, by the courtesy of Capt. Douglas Galton, I hope to bring before the British Association of this autumn. But a brief summary of results is as follows :-

On June 5 I reached the ward at $9.40 \mathrm{a} . \mathrm{m}$. The rigor had begun at 8.30 and was beginning to decline; I had time, however, for the following determinations :-

$\begin{array}{rcccccc}940 \ldots & \ldots & \ldots & \ldots & \ldots & \text { R. } 4140 & \text { ohms. } \\ 9.55 \ldots & \ldots & \ldots & \ldots & \ldots & , 3470 & , \\ \text { I0.10... } & \ldots & \ldots & \ldots & \ldots & , 32900 & \text {," }\end{array}$

These measurements were taken with a very small E.M.F. of about 9 volts. On June 9 I succeeded in reaching the ward during the beginning of the rigor, and took the following measurements, this time with corresponding temperatures:-

$$
\begin{aligned}
& \text { ro.30 a.m. } \quad \ldots \quad \ldots \quad \text { Temp. } 102^{\circ} 4 \quad \ldots \quad \text { R. } 4550
\end{aligned}
$$

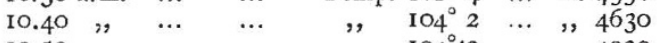

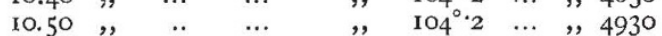

At this point the rigor, temperature, and resistance began to descend. I visited the patient again at

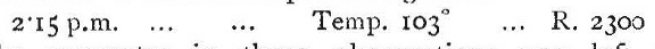

The apparatus in these observations was left untouched, so as to prevent any accidental change. The measurement was made with a double E.M.F. to those preceding, namely, 18 volts. I determined on each occasion the resistance of the leads and terminals, which I found to be on each occasion 2 ohms.

I cannot help thinking that the difference, which is as nearly as possible twice the smaller amount, is too great to be accounted for by any instrumental error, and that the human body, in spite of its large amount of liquid constituents, follows a similar thermal law of resistance to that influencing solid conductors, though in a very much bigher ratio.

Only one other point requires comment, namely, the mode of making contact between the body and the testing apparatus. Prof. Rosenthal in the communication quoted above draws attention to the high insulating powers of the epidermis. In the above experiment I passed the current through the two legs, from one foot to the other, in alternate directions. The feet were previously soaked in salt and water; two large pans containing about a quart of brine each were then placed under the feet, and in each was immersed a plate of copper five inches square connected with the bridge by stout cables. I have found in other experiments that after half an hour the resistance ceases to decrease, a.d in this experiment it actually increased to the amount of 480 ohms. The whole foot was immersed, its sole resting directly on the copper plate. I have two other methods of making contact in use. The first consists of rubbing the skin with the oleate of mercury; which to the diffusion power of oleic acid adds the conductivity of its base, and then immersing the part in metallic mercury. The other consists of inserting small silver claw-forceps, known to surgeons as "serrefines," through the epidermis into the tissue below. This is rather painful, but not more so than I find medical students eager in the pursuit of knowledge can and will easily undergo.

W. H. STONE

\section{THE AMBER FLORA}

7'HIS is the first volume of a work on the flora of the amber-bearing formations of East Prussia, and is devoted exclusively to Coniferæ. The introduction contains a sketch of the geological history of the order, and among much that is of interest we find an estimate that the existing Coniferæ occupy an area of about 3,000,000 square miles (500,000 German). The described fossip species are now almost as numerous as the living ( 400 to 450), though a revision might reduce their number by one-half. The colossal dimensions of some of the living Coniferæ are familiar to most, but it is not generally known how nearly these are rivalled by fossil species. Examples are given, as of a stem of Cupressinoxylon ponderosum, broken at both ends and 200 feet long, and another 12 to 14 feet across; a stem of Araucarites, 25 feet in circumference, and a silicified stem from California, 33 feet round the butt.

A considerable portion of the work is occupied with a minute and splendidly illustrated inquiry into and description of the microscopic structure of the tissue of existing and fossil Coniferæ, especially with regard to their resinsecreting organs. Goeppert claims to have originated this study forty years ago, and is certainly the chief authority in it. The result of his work shows that the Abietineæ, or fir tribe, have almost alone contributed the amber, and that at least six species produced it, the chief being close allies of the Common Spruce and the American Pinus strobus. These possess three separate sets of resin-producing organs chiefly situated in the cambium layers, which are in the form of cells and ducts running in both horizontal and vertical directions, and appearing at a very early stage of growth. Some Pines are liable to frost-cracks, and into these the resin collects and thence exudes, keeping the wound from healing and furnishing a perpetual supply. Very few specimens of amberwood preserve the bark layers with the resiniferous organs, but sufficient is seen to prove that these in no way differed from those of the Abietineæ at the present day, especially of the Spruce.

The most important section of the work probably is the research into the microscopic structure of the wood, which is, however, of an extremely technical nature. Five separate species of Pinus are recognised by their wood, and a very rare and doubtful wood-structure is referred to the Taxineæ.

More interesting perhaps to the general reader are the descriptions of fragments of foliage and fructification inclosed in the amber. Insignificant as the figured specimens appear, they are yet in so marvellous a state of preservation that their texture and microscopic structure, and even the glaucous colouring of the under sides of some of the leaves are visible. Twenty species are determined, with a tendency, it is pleasing to find, rather to curtail than to multiply the number previously des ribed. They have been studied with extraordinary care, and the results are consequently unusually satisfactory.

1 "Die Flora des Bernsteins." R. Goeppert and A. Menge, Naturforshenden Gesellschaft in Danzig. 4to, $188_{3}$. 
The ABIETINeÆ are represented by 2 Pines of the Tada and 2 of the Pinaster section, and by 2 Firs. It is impossible, with the material, to more than guess at the affinities of the fossil with the existing species in such an immense tribe, but 3 are compared with American, and I with a European species. The presence of 2 species of the Parasol Fir of Japan is of especial interest, if the appearance of a double midrib on the back of the leaf is a reliable character, but a doubt seems to be expressed in the altered termination of the name, "Sciadopites." Nearly all the rest are CUPRESSINEA, and many are represented by catkins and foliage. The Widdringtonias, a section of Callitris confined to the Cape and Madagascar, are represented by 2 species. The almost ubiquitous Tertiary Libocedrus salicornioides, allied to the Chilian Incense Cedar, is indisputably present, even its glaucous colour being preserved. Two Thuyas are indistinguishable from the Chinese and the American Arbor-Vitæ, and a more doubtful form is nearly related to the Thuyopsis dolabrata of Japan. A male catkin exactly resembling that of the Red Cedar of Virginia (from which pencils are made) represents the Junipers, and this extraordinary assemblage is completed by the presence of the common European Cupressus. The TAXODIEE, again, are represented by Sequoia Langsdorfii, a widespread and somewhat northern Tertiary Conifer, closely allied to the Californian Red Wood; Taxodium distichum, the Deciduous Swamp or Bald Cypress of Virginia, and the well-known Tertiary, Glyptostrobus, all but indistinguishable from the living Chinese species. The last described is an American type of Ephedra, or Jointed Fir.

A group of Coniferæ must therefore have existed in Europe, almost on one spot, comprising representatives from nearly every Geographical Province. There were present such magnificent representatives of the Californian Coniferæ as the Red Wood, the Sugar Pine, the Douglas Spruce, the scarcely less majestic Bald Cypress, Red Cedar, Thyua, and Pinus rigida of more eastern States, the Chilian Incense Cedar, the Parasol Fir, the Arbor-Vitæ, the Glyptostrobus, and the Thuyopsis of the Eastern Coasts of Asia, the Scotch Fir, the Spruce and the Cypress of Europe, and the Callitris of Southern Africa. Based on the careful research of a man who has made Coniferæe his especial study for fifty years, these determinations have a value which the haphazard methods of so many workers. in Fossil Botany do not possess. The causes which led to the dispersion and extinction in Europe, in such relatively recent times, of so considerable a group of Coniferæ would be interesting to tracc out.

The similarity between the Amber Flora and the overlying Brown-coal Flora, described by Heer, lead to the inference that its age must be Middle Miocene. The deposits are uniformly sand, clay, and loam, in which are imbedded partly rolled stones of various kinds and sizes. The whole belongs to a vast and widely spread amberbearing "diluvial formation" which stretches from the confines of the White Sea into Holland. The richest deposits are situated along a strip of coast between Memel and Dantzic, but the real home of amber has been supposed to lie in the bed of the Baltic between Bornholm and the mainland. It rests upon Cretaceous rocks, and consists chiefly of their debris, forming a peculiar mixture known as "blaue-Erde," which appears to exist throughout the Province of Samland at a depth of 80 to 100 feet, and to contain an almost inexhaustible supply of amber. The authors wish to correct the name to "blau-grün," to distinguish it from the blue earth which accompanies the brown coal in Silesia and elsewhere. Immense quantities of amber are washed out to sea from the coast, or brought down by rivulets and cast up again during storms or in certain winds. The expectations that amber-bearing beds of equal richness would be found at greater depths farther from the sea have not been realised, and these already priceless and apparently inexhaustible coast-deposits have thereby acquired an enhanced importance. It seems probable that the amber-beds of the North Sea belong to the same formation, and that these may even have been continuous to the east coast of Great Britain.

Though the greatest quantity of amber is found on the coast, the largest pieces, 6.5 and 9.5 kilos., were met with inland. It is never found in paying quantities at a greater depth than 4 to 6 feet, and chiefly in the "diluvial beds" with rolled fragments of brown coal, wood, and stones. It is rare in the brown-coal formation, and even when met with is almost confined to the Upper blue and plastic clays. The quantity, however, seems to be inexhaustible, for the rich and celebrated blue-earth of Samland extends along the coast for 60 miles, and possesses a breadth of about 12 miles and an average thickness of ro feet. Runge estimates that each cubic foot contains $\frac{1}{12} \mathrm{lb}$. of amber, which gives a total of some $9,600,000,000$ lbs. The actual yield at present is 200,000 to $300,000 \mathrm{lbs}$. per annum, or at least five times the quantity estimated to be cast up by the waves of the Baltic on this coast, so that it appears, at the present rate of quarrying, there is a supply for some 30,000 years to come. A good deal of amber, it must be remembered, is cast up on other Baltic shores and along the North Sea.

In an inquiry as to the probable extent of Pine forests that would be required to produce such a bulk of amber, the authors take the Norway Spruce (Pinus abies, Linn.) for the purpose of comparison. Estimating that the full age of the species is I 20 years, sixty to seventy of which are resin-producing, they conclude that $6000 \mathrm{lbs}$. per acre would be the product of each generation, and therefore that the Baltic Sea, with its area of 6370 German miles, might yield, if covered with Norway Spruce, $8,408,400,000$ lbs., or about an equivalent to the quantity contained in the 20 German square miles of the Samland "blue-earth" referred to above. It thus appears that if this amber in it had been produced on the spot, some 300 generations would have been required to furnish it, but it is of course far more probable that it has been collected together in its present position by the action of water. These estimates being founded on a species relatively poor in resin, even notoriously less resinous than Pinus austriaca and other existing species, it is likely that the amber yield was in excess.

The Amber Flora presents a group of cryptogams comprising 20 Fungi, I 2 lichens, and about as many mosse; -plants hardly represented in any other Tertiary Flora. It is united to other Miocene Floras, not only by its Coniferæ, but by the widely-spread Cinnamonum polymorphum. It contains 42 species of Conifers, Cupuliferæ, Betuleæ, Salicineæ, \&c., a species of Hakea, in all 27 Monopetalæ and 12 Polypetalæ, including such rarely preserved orders as Scrophulariaceæ, Primulaceæ, Caprifoliaceæ, and Loranthaceæ, the gatherings from forest, meadow, and fen. These are to be described in a fortbcoming work. The Coniferæ are, however, of chiefest interest, more especially as, while resembling the resinous species of the present day, their secretions differed so essentially in quality as to have left a product unknown in any other geological age.

\section{J. Starkie Gardner}

\section{THE STORY OF A BOULDER}

$\mathrm{THE}$ Warwickshire papers report a curious open-air service held on Sunday last at Stockton, near Rugby, to "consecrate" a large granite boulder which has been inscribed and railed in at the expense of the villagers. It lies on a bed of concrete in the centre of the little place, protected by a handsome iron railing; a few square inches are polished to show the grain; an inscription records that it was brought from Mount Sorrel, a distance 